\title{
90歳前後の口腔，唾液腺癌患者に対する臨床・免疫学的検討
}

\author{
広田重水・尾崎登喜雄・米田和典 \\ 山本哲也・植田栄作・松木宏真
}

\section{A clinico-immunological investigation in extremely aged patients, about 90 years old, with oral and salivary gland malignancies}

\author{
Jusui Hirota • Tohio Osaki • Kazunori Yoneda \\ Tetsuya Yамамото • Eisaku Ueta • Hiromasa Matsugi
}

\begin{abstract}
This article dealt with extremely aged (about 90 years old) patients (2 males and 8 females) with oral or salivary gland malignancies which were treated in our clinic during the last 10 years. The following results were obtained in clinico-immunologic studies comparing these patients with younger cancer patients and healthy individuals.

1. Histologically, 7 tumors were squamous cell carcinoma which originated from the gingiva except for one case, 2 were of salivary gland origin, and one was malignant lymphoma. Out of the 9 carcinomas, 5 were in stage $\mathbb{I V}$.

2. Most patients originally had multiple complications and disabilities.

3. Compared to younger patients and healthy controls, significant decreases of Leu $8^{+} \mathrm{T}$ cells, lymphocyte blastogenesis, $\mathrm{NK}$ activity, and a significant increase of $\mathrm{CD} 16^{+} \mathrm{CD} 57^{+}$ cells were observed, while LAK activity and $\mathrm{O}_{2}^{-}$generation of neutrophils were not suppressed.

4. Six patients received radical treatment, and four received non-radical treatment. All tumors were locally controlled, while metastatic lymph nodes became uncontrollable in one of the $3 \mathrm{~N}(+)$ cases.

5. Except for one case, adverse effects such as bone marrow suppression and stomatitis were observed. Among these effects, decreases is white blood cells and cholinesterase persisted even after discharge.

These results indicate the importance of considering both psychological and physiological conditions unique to highly aged patients when deciding therapy principles for them. Moreover, local treatment such as radiation and surgical excision avoiding impairment of the patient's quality of life is advantageous for extremely aged patients.
\end{abstract}

Key words : extremely aged patients (超高龄患者), oral malignancy (口腔悪性腫瘍), NK and LAK activity (NK \& LAK 活性), lymphocyte subsets (リンパ球サブセット), complications (合併症)

緒言

わが国の人口高秢化は急速に進み，高跘化社会に突入
しつつある，高齢化に 伴い高齢患者は増加し，悪性腫 漡においても高齢者の占める割合は增加の一途をたど $り^{1,2)}$ ，高㱓癌患者にいかに対処するかが避けて通れな い大きな問題となってきた。高秢者には高齢者特有の精
高知医科大学医学部㴹科口腔外科学教室

（主任：尾崎登喜雄教授）

Department of Oral Surgery, Kochi Medical
School (Chief: Prof. Tokio Osaki)

受付日：平成 4 作 7 月 30 日 
神状態と生理が存在する ${ }^{3,4)}$. したがって，高秢者に刘 しては患者の精神・生理上の特徴を理解した上で, バラ ンスのとれた治療が要求される。特に顎・腔領域は会 話, 咀嚼, 燕下といった機能を有し, これらの機能は高 秢者の「生きる楽しみ」に直結している，もし癌治療に よって口腔の諸機能が障害されることとなると, 生理们 機能障害に止まらず精神的負荷も加わり, Quality of life（QOL）を大きく損ならこととなる。 それゆえ，高 踰および口腔の特殊性を配慮した上での，きめ細かな治 療が必要とされる.今回, 高龄癌患者が内包する諸種の 問題点をあきらかにすべく，90歳前後で治療した10例の 頭頸部癌を対象にして, 臨床的に検討した。 その結果, 二，三の点をあきらかにしえたので報告することとし た.

\section{対象と方法}

対象とした患者は，1981年10月より1992年 5 月までの 間に加療した頭頸部悪性腫瘍入院患者 182 例（図 1) の らち，90藏以上で治療を行った 4 例, 治療後 90 歳以上ま で生存した 6 例の計 10 例である。これらの症例に対し て, 腫瘍の発生部位, 組織型, 病期, そして治療法, 治 療に伴う合併症および各検查值の変動，さらには子後お よび治療後の生活内容 (QOE) について検索した。 採血 は治療前 (入院時), 化学/放射線治療終了から10日前後 経過した時点扣よび退院時とした。末梢血リンパ球およ び好中球は比重遠沈法によって分離した，末梢血りンパ 球の構成比はフローサイトメトリー法で行い, リンパ球 幼若化は Phytohemagglutinin P (PHA: $1 \mu \mathrm{g} / \mathrm{ml}$ ) およ び Concanavalin A Con A: $10 \mu \mathrm{g} / \mathrm{m} l$ ) を用い, [ $\left.{ }^{3} \mathrm{H}\right]$ でラベルしたサイミジン ( $\left[{ }^{3} \mathrm{H}\right] \mathrm{TdR}: 1 \mu \mathrm{Ci} /$ well $)$ の取 り込み量でもって测定した. Natural killer (NK) およ び Lymphokine-activated killer (LAK) 両活性は ${ }^{51} \mathrm{Cr}$ リリースアッセイ法を用いた。標的細胞はそれぞれ $\mathrm{K}$ 562 細胞および Daudi 細胞とし， E/T 比は $25: 1$ と した. LAK 細胞は recombinant interleukin-2 (rIL-2: $70 \mathrm{JRU} / \mathrm{ml}$ ) の存在下で 3 日間培養して誘導した。好中 球のスーパーオキサイド $\left(\mathrm{O}_{2}^{-}\right)$産生はチトクローム $\mathrm{C}$ 罡 元法により測定したが, 刺激剂として phorbol ministrate acetate (PMA: $50 \mathrm{ng} / \mathrm{ml}$ ) を用いた.

QOL の判定にあたっては，精神，身体阿活動を伻㑣 し，何ごとも自分ででき，日常生活を楽しむことができ る (Good), 多少の障害はあるものの身の问りのことは ほとんど自分でできる（Fair），就床せざるをえないか， あるいは介助が必要 (Poor) の 3 段階に分けた. QOL の判定は初診時と退院後に行った。 なお，末梢血検査は 40 歳以上 60 歳未満の口腔癌患者 38 例および健常人コント ロールとして, 健康な18歳から73歳にわたる20人を対象 に検討した。

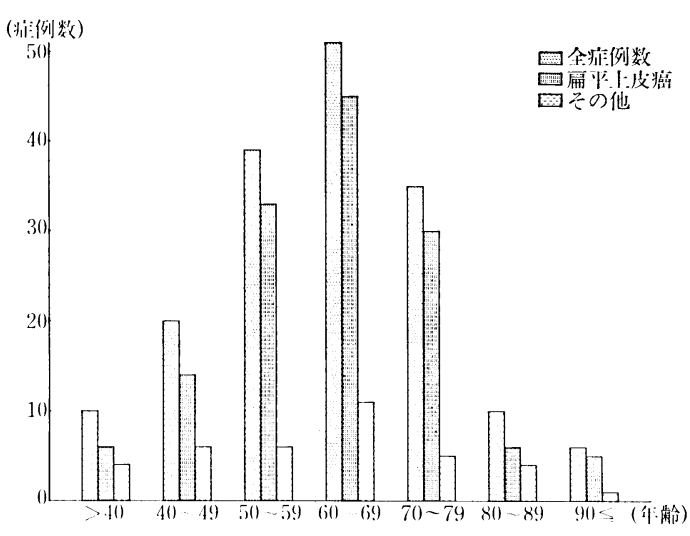

図 1 想性腫瘍患者の俳踰別症例数

対象患者の初診時年撂は87藏から94歳にわたり, 平均 89.9歳であった（表 1 ）。腫瘍は煩粘膜に原発した腺癌, 耳下腺の粘表皮滰，下顎歯肉に生じた悪性リンパ腫のそ れぞれ 1 例を除き, 残る 7 例はいずれも扁平上皮癌で, このらち上顎米肉, 下顎歯肉がそれぞれ 3 例, 煩粘膜が 1 例であった．悪性リンパ腫を除く癌腫の Stage は T2, $\mathrm{T} 3$, T4 が各 3 例, リンパ節転移のみられたもの $(\mathrm{N}+)$ 3 例, 転移の認められなかったもの $(\mathrm{N}-) 6$ 例で, Stage II 3 例, Stage III 1 例, Stage IV 5 例となり, 進 行癌が過半数を占めていた。

合併症は入院時すでに全例に認められ，1 例を除く9 例が複数の障害を保有していた. 中でも心・血管系障 害, 换父障害がともに 8 例と最も多く, 次いで難聴, 歩 行障㕩がそれぞれ 3 例, 負血, 白内障が各 2 例, その 他, 臛能障害, 低蛋白血症がそれぞれ 1 例に認められ た.一方，精神活動は全例支障なく，QOL は Good 1 例, Fair 7 例, Poor 2 例であった.

治療開始時における対象の末梢血リンパ球構成比と白 IfII球機能を対照癌患者そして健常人と比較してみると, 刘象患者の $\mathrm{T}$ 紐胞 $\left(\mathrm{CD}^{+}{ }^{+}\right.$細胞）比は他に対して有意で はないものの $54.7 \pm 15.4 \%$ と低下していた（表 2). 逆 に, HLA-DR 陽性T紐胞は $10.6 \pm 5.8 \%$ と健常人の值 よりも有意に高值であったが, 本サブセットの上昇は対 照患者においても同程度観察された。癌患者では健常人 に比して CD4 ${ }^{+}$紐胞, $\mathrm{CD}^{+}$細胞ともに Leu8- 細胞比 が高く，Leu8 ${ }^{+}$細胞比が低い傾向にあった。 そして，こ の傾向は高秢患者においてょり顕著で, CD8 Leu8 ${ }^{+}$細 胞比は $3.5 \pm 2.4 \%$ と対照患者の $6.7 \pm 3.6 \%$ より有意に 低值であった．NKサブセットの中で CD57+ 細胞比は， 刘照患者では健常人との閏に差はみられなかったもの 
表 1 刘娐症例の㹂休的内訳

\begin{tabular}{|c|c|c|c|c|c|c|c|}
\hline 症例 & 初診時作:踰 & 性 & 部 位 & 組 織 型 & 狱 则 & 合 併 症† & QOL \\
\hline 1 & 94 & $\mathrm{~F}$ & 沵 & 腺 陪 & T2aN0M0* & AP, LVH, RVI, HH & Good \\
\hline 2 & 88 & M & 耳下腺 & 粘表皮蕌 & T4bNoM0 & $\mathrm{AV}, \mathrm{OVI}$ & Fair \\
\hline 3 & 91 & $\mathrm{~F}$ & 上:顎䧒肉 & 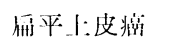 & T2N0M0 & AP, PAC, RVI & Fair \\
\hline 4 & 89 & $\mathrm{~F}$ & 1:顎雨肉 & 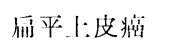 & T3N2cM0 & HT, CI, Ane, Con, HH, HW, CVI & Poor \\
\hline 5 & 89 & $\mathrm{~F}$ & 下顎詸肉 & 两平上:波消 & T3N0M0 & HT, LVH, PVC, HPE, HW, CVI & Poor \\
\hline 6 & 92 & $\mathrm{~F}$ & 下顎㜆肉 & 会平上:皮㹳 & T4N0M0 & AP & Fair \\
\hline 7 & 92 & $\mathrm{~F}$ & 下顎幽肉 & 两平上皮緥 & T3N2bM0 & $\mathrm{AV}, \mathrm{RVI}$ & Fair \\
\hline 8 & 89 & $\mathrm{~F}$ & 媔 粘膜 & 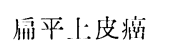 & $\mathrm{T} 4 \mathrm{~N} 1 \mathrm{M} 0$ & Ane, $\mathrm{HH}$ & Fair \\
\hline 9 & 89 & $\mathrm{~F}$ & 1:顎㮫肉 & 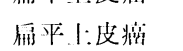 & T2N0M0 & LDF, OVI & Fair \\
\hline 10 & 87 & $\mathbf{M}$ & 下顎㳡肉 & 想性リンパ朠 & $\mathrm{CS} \mathrm{I}_{\mathrm{E}}^{\dagger}$ & CI, RVI, Con, HW & Fair \\
\hline
\end{tabular}

* : UICC (1987华）の分類 ${ }^{5)}$, $\dagger:$ Ann Arbor の纺期分類 ${ }^{6)}$

‡: AP 狭心症, CI 脳梗塞, HT 高血圧症, LVH 左窒肥大, AV $1^{\circ}-\mathrm{AV}$ block, PAC 心房性期外収縮, PVC 心室性期外収縮, RVI 拘束性換気障哲, OVI 閉塞性換気障害, CVI 混合性換気障害, Ane 貧血, HPE 低 蛋白血症, LDF 肝㙨能障皆, Con 白内障, HH 難聴, HW 歩行障害

表 2 治療逝の患者木柎伹リンパ球構成比と白血球機能*

\begin{tabular}{|c|c|c|c|}
\hline & 対像患者 & 対照患者* & 対照健常人† \\
\hline CD3 & $54.7 \pm 15.4$ & $61.6 \pm 12.1$ & $60.4 \pm 10.1$ \\
\hline CD3DR & $10.6 \pm 5.8^{\mathrm{a} 1}$ & $9.1 \pm 3.9$ & $4.8 \pm 2.2$ \\
\hline CD4 Leu $8^{-} \quad(\%)$ & $16.7 \pm 5.8^{\mathrm{a} 1}$ & $14.1 \pm 6.7$ & $10.9 \pm 5.3$ \\
\hline CD4 Leu8 ${ }^{+} \quad(\%)$ & $17.4 \pm 8.6^{\mathrm{a}^{3}}$ & $25.8 \pm 10.8$ & $25.2 \pm 8.5$ \\
\hline CD8 Leu8 ${ }^{-} \quad(\%)$ & $13.2 \pm 7.5^{\mathrm{a}^{2}}$ & $10.8 \pm 5.5$ & $7.3 \pm 2.8$ \\
\hline CD8 Leu8 ${ }^{+} \quad(\%)$ & $3.5 \pm 2.4^{\mathrm{a} 2, \mathrm{~b} 1}$ & $6.7 \pm 3.6$ & $9.8 \pm 6.2$ \\
\hline $\mathrm{CD} 16^{+} \mathrm{CD} 57^{-}(\%)$ & $5.5 \pm 2.5$ & $4.9 \pm 2.5$ & $5.0 \pm 1.9$ \\
\hline $\mathrm{CD} 16^{+} \mathrm{CD} 57^{+}(\%)$ & $13.7 \pm 9.6^{\mathrm{a}^{3}, \mathrm{~b} 2}$ & 7.5 土 4.9 & $7.3 \pm 6.1$ \\
\hline $\mathrm{CD} 16^{-} \mathrm{CD}^{-} 7^{+}(\%)$ & $14.8 \pm 3.7$ & $14.2 \pm 6.7$ & $12.1 \pm 7.7$ \\
\hline PHA $\left(\times 10^{4} \mathrm{dpm}\right) \ddagger$ & $10.4 \pm 6.6^{\mathrm{a} 2, \mathrm{~b} 2}$ & $19.0 \pm 11.2$ & $24.4 \pm 10.2$ \\
\hline $\operatorname{ConA}\left(\times 10^{4} \mathrm{dpm}\right)$ & $6.1 \pm 3.4^{\mathrm{a} 2}$ & $7.6 \pm 5.0$ & $13.5 \pm 6.5$ \\
\hline NK 活性 $\quad(\%) \S$ & $25.2 \pm 7.2^{\mathrm{a}^{2}, \mathrm{~b} 2}$ & $38.7 \pm 18.0$ & $38.4 \pm 10.6$ \\
\hline LAK 活性 $(\%) \|$ & $60.5 \pm 9.5$ & $58.3 \pm 14.8$ & $69.5 \pm 10.3$ \\
\hline $\mathrm{O}_{2}^{-}$座生 $\left(\mathrm{pmol} / \mathrm{min} / 10^{4}\right.$ cells $)$ ๆ & $84.9 \pm 31.7$ & $75.5 \pm 22.5$ & $110.5 \pm 31.0$ \\
\hline
\end{tabular}

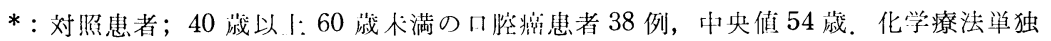

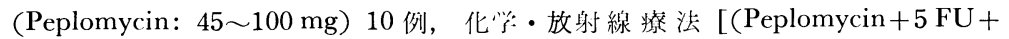
Radiation (24 40 Gy) 28例。 $†$ : 刘热健篎人 (20人)；18７3藏, 中央值 48 歳

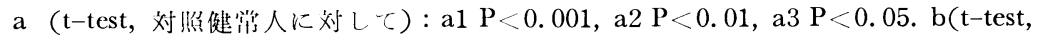
刘热㭧者に刘して)：b1 $\mathrm{P}<0.01, \mathrm{~b} 2 \mathrm{P}<0.05$

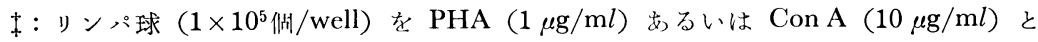

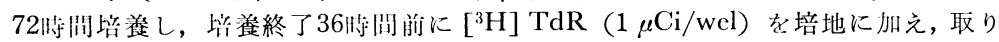
込まれた $\left[{ }^{3} \mathrm{H}\right] \mathrm{TdR}$ の量炎测定した。

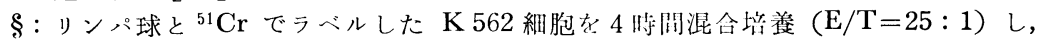
放出された ${ }^{51} \mathrm{Cr}$ の量を测定した。

$\|$ : リンパ球を $\mathrm{rIL}-2(70 \mathrm{JRU} / \mathrm{ml})$ で 3 日间培養し, 誘導された LAK 細胞の

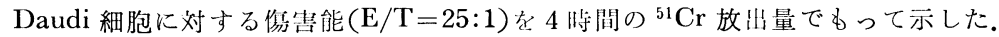

I: 好中球 $\left(1 \times 10^{6}\right.$ 湖 $\left./ \mathrm{ml}\right)$ を PMA $(50 \mathrm{ng} / \mathrm{ml})$ で刺激し, チトクロームC 還元法 により㦃生された $\mathrm{O}_{2}^{-}$㥕尖量した。 
表 3 治療内得とその缅炢效果，副作用について

\begin{tabular}{|c|c|c|c|c|c|c|c|c|}
\hline 症例 & $\begin{array}{l}\text { 治療 } \\
\text { 方針 }\end{array}$ & 化学療法 $(\mathrm{mg}) *$ & 放射線 & $\begin{array}{c}\text { 尖施用量 } \\
\text { 予䀺用量 } \\
\quad \times 100\end{array}$ & 免 忮 & 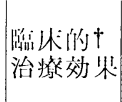 & 辰 術 & $\begin{array}{l}\text { 副作用/ } \\
\text { 僦発疾忠 }\end{array}$ \\
\hline 1 & 根治的 & ND & $30 \mathrm{~Gy}$ & $100 \%$ & ND & PR & 縮小術 & 口内炎 \\
\hline $2^{\mathrm{a}}$ & 姑息的 & $5 \mathrm{FU}: 2,250$ & $30 \mathrm{~Gy}$ & $100 \%$ & $\mathrm{OK}-432: 20 \mathrm{KE}$ & - & 減据于術 & な L \\
\hline $3^{b}$ & 根治的 & PLM: $30,5 \mathrm{FU}: 2,375$ & $32 \mathrm{~Gy}$ & $60 \%$ & LAK & CR & ND & 口内炎 \\
\hline $4^{\mathrm{c}}$ & 姑息的 & PLM:20 & $40 \mathrm{~Gy}$ & $100 \%$ & LAK & CR & ND & $\begin{array}{l}\text { 口内炎, 沉 fill } \\
\text { 球減少 }\end{array}$ \\
\hline 5 & 姑息的 & PLM:20, 5FU:2, 375 & $40 \mathrm{~Gy}$ & $100 \%$ & $\mathrm{OK}-432: 4 \mathrm{KE}$ & PR & ND & $\begin{array}{l}\text { 口以炎, 腰椎 } \\
\text { 肾折 }\end{array}$ \\
\hline 6 & 姑息的 & $\begin{array}{l}\text { PLM: } 35,5 \mathrm{FU}: 2,750 \\
\text { CDDP: } 40\end{array}$ & ND & $80 \%$ & ND & SR/NR & ND & 口内炎, 帅炎 \\
\hline 7 & 根治的 & PLM: 45, 5FU:3, 000 & $30 \mathrm{~Gy}$ & $100 \%$ & $\mathrm{OK}-432: 45 \mathrm{KE}$ & PR & $\begin{array}{l}\text { 根治似 } \\
\text { 经淯就沙術 }\end{array}$ & $\begin{array}{l}\text { 口内炎, 沉 Ifll } \\
\text { 球娍少 }\end{array}$ \\
\hline 8 & 根治的 & PLM: 90 & $20 \mathrm{~Gy}$ & $100 \%$ & $\mathrm{OK}-432: 20 \mathrm{KE}$ & CR & 烦激郘清術 & 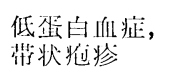 \\
\hline 9 & 根治的 & PLM:5, 5FU: 1,500 & $\mathrm{ND}$ & $20 \%$ & $\mathrm{ND}$ & SR/NR & 維小術 & 汹 Ifll球減少 \\
\hline 10 & 根治的 & $\begin{array}{l}\text { CPM : } 1,600, \text { ADM }: 100 \\
\text { VCR: } 4, \text { PLM: } 30\end{array}$ & ND & $100 \%$ & ND & CR & ND & $\begin{array}{l}\text { 脱E，肺機能 } \\
\text { 障皆 }\end{array}$ \\
\hline
\end{tabular}

* : PLM (Peplomycin, iM), 5FU (iV), CDDP (Cisplatin, iV), CPM (Cyclophosphamide, iM), ADM (Adriamycin, iV), VCR (Vincristine, iV)，な打症例 4，5 は動涯例。

$\dagger$ : CR: complete response（縮小率100\%), GR: good response（縮小懐90\%以 以:), PR: pertial response(縮 小率50 90\%), SR/HR：slight response/not response（縮少摔50\%以下)，LAK： lymphokine activated killer cells, ND: not done

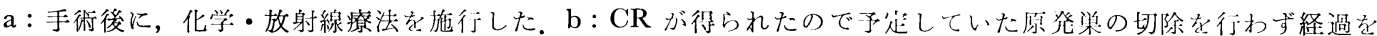
観察した。 $\mathrm{c}: \mathrm{N}_{2} \mathrm{c}$ であったことょり，姑息的治療存蛄执した。

の，対象患者では $\mathrm{CD} 16^{+} \mathrm{CD} 57^{+}$は13.7土9.6\% と健常 人 $(7.6 \pm 6.1 \%)$ に比し有意に高值であった。一方，リ ンパ球幼若化は癌患者, 特に高路患者で少り, PHA, ConA 刺激下に和いて，それぞれ10.4土6.6×104 dpm， $6.1 \pm 3.4 \times 10^{4} \mathrm{dpm}$ であり，対照患者（それぞれ 19.0 土 $11.2 \times 10^{4} \mathrm{dpm}, 7.6 \pm 5.0 \times 10^{4} \mathrm{dpm}$ ) 扎よび健常人（そ れぞれ $\left.24.4 \pm 10.2 \times 10^{4} \mathrm{dpm} ， 13.5 \pm 6.5 \times 10^{4} \mathrm{dpm}\right)$ と の間に有意差が認められた。 NK 活性にも有意差が㤮め られ，健常人および対照患者ではそれぞれ $38.4 \pm 10.6 \%$ ， $38.7 \pm 18.0 \%$ であったのに対し，対象患者では 25.2 土 $7.2 \%$ ，有意に低值であった。しかしながら，LAK 活 性は 3 群とも $60 \%$ 前後で大きな差はなく，さらには $\mathrm{O}_{2}^{-}$ 産生も患者群では $80 \mathrm{pmol} / \mathrm{min} / 10^{4} \mathrm{cells}$ 前後で, 健常人 の $110.5 \pm 31.0 \mathrm{pmol} / \mathrm{min} / 10^{4}$ cells に比べやや劣るもの の，両者の間に有意差は認められなかった。

治療は腫瘍進展度, 全身状態, そして病理組織所見に よって総合的に決定された。 その結果，6例に根本似治 療が，4 例に姑息的治療が計画された（表 3).これら のらち，2 例は，副作用により予定された治療が完遂で きず，根本治療は 4 例にのみ施行された。これら 4 例の 中で, $\mathrm{CR}$ と PR が 2 例ずつ得られ, 後者に対しては, 縮小術（症例 1 ）および根治術（症例 7 ）が施行され
た。これに刘して，予䇥された根本的治療が完遂しえな かった 2 例のうち 1 例（症例 3 ）は悇で終わったもの の，CR が得られた。それゆ光，症例 3 には手術を行わ ず経過を観祭した。他の 1 例（症例 9 ）は十分に反応を 亦さなかったものの，上顎洞を開放する根本的手術は患 者にとってかえって不利と考えられ，齿槽骨を切除する にとどめた。一正，当初より奴息们治療が試みられた 4 例のうち，粘此支澏の 1 例（症例 2 ）には減量手術につ づき化学/放射線療江济追加され, 残る 3 例には化学療 法単独, あるいは化学/放射線療泣が施行され, 手術は 行われなかった。これら 3 例に打ける治療効果は, LAK 療法が組み入れられた 1 例（症例 4 ）にCR が得られた ものの, 残る 2 例では, PR（症例 5 ), SR/NR（症例 6) であった.

初以治療の後，5 例に局所再発が認められた（表 4). 根本的治療が可能と考えられた 3 例（症例 $3 ， 8 ， 9$ ) には于:術が，そして姑思似治療の適応と考えられた 2 例 （症例 $2 ， 5$ ）に対しては保存的治療が用いられ，いず れも最終的には局所制御が得られた。転移りンパ節が認 められた 3 症例（症例 $4 ， 7 ， 8$ ）のらち, コントロ一 ルできたのは 1 例のみで，他は将発をきたした。再発し た 2 例のうち 1 例（症例 4 ）には外照射が追加され，そ 
表 4 予後扣よび死亡状況

\begin{tabular}{|c|c|c|c|c|c|c|c|c|}
\hline \multirow{2}{*}{ 症例 } & \multicolumn{2}{|c|}{1 次治療後の経過 } & \multirow{2}{*}{ 生死/直接死因 } & \multirow{2}{*}{$\begin{array}{l}1 \text { 次治療開始か } \\
\text { ら 告生存期間 }\end{array}$} & \multirow{2}{*}{$\begin{array}{l}\text { 平均 } \\
\text { 余命 } †\end{array}$} & \multirow{2}{*}{$\begin{array}{l}\text { 生存中の } \\
\text { QOL }\end{array}$} & \multirow{2}{*}{$\begin{array}{l}\text { 死亡時 } \\
\text { 年 齢 }\end{array}$} & \multirow{2}{*}{$\begin{array}{l}\text { 死亡 } \\
\text { 場所 }\end{array}$} \\
\hline & 局 所 & リンパ節 & & & & & & \\
\hline 1 & - & - & 生 存 & 2作 7 か月 & 2.6 年 & Good & - & - \\
\hline 2 & {$[(\mathbf{R}) \rightarrow \stackrel{+}{+} \underset{\text { 制御 }}{ }] \times 2$} & - & 死亡/心不全 & 4 年 8 か月 & 3.8 脌 & Fair & 92歳 & 近医 \\
\hline 3 & $(\mathrm{C}+\mathrm{R}+\stackrel{+}{\mathrm{S}}) \rightarrow$ 制御 & - & 死亡/心不全 & 1 年 2 か月 & 3.5 年 & Fair & 92歳 & 自宅 \\
\hline 4 & - & $(R) \stackrel{+}{\rightarrow}$ 制御 & 死亡/老哀 & 11か月 & 4.2 年 & Fair & 90歳 & 自宅 \\
\hline 5 & $(\mathrm{C}+\mathrm{R})^{+} \rightarrow$ 制御 & - & 死亡/心不全 & 2 作 4 か月 & 4.1 年 & Fair & 92歳 & 自宅 \\
\hline $6^{*}$ & - & - & 死亡/肺炎 & 3 か月 & 3.2 年 & Poor & 92歳 & 当院 \\
\hline 7 & - & （治療行わず） & 死亡/肺炎 & 5 か月 & 3.2 年 & Poor & 92歳 & 近医 \\
\hline 8 & $(\mathrm{C}+\mathrm{R}+\mathrm{S}) \rightarrow$ 制御 & - & 死亡/老衰 & 5 们 4 か月 & 3.8 年 & Fair & 94歳 & 自宅 \\
\hline 9 & $\left(\mathrm{C}+\mathrm{S}^{+} \rightarrow\right.$ 制御 $^{2}$ & - & 死亡/脳出 IIIL & 2 俳 4 か月 & 3.8 作 & Fair & 91藏 & 自宅 \\
\hline 10 & - & - & 生 存 & 4 年: 3 か月 & 4.2 年 & Good & - & - \\
\hline
\end{tabular}

（）内は 2 次治療。 $\mathrm{C}$ ：化学療法， $\mathrm{R}$ ：放射線療法, $\mathrm{S}$ ：手術療法

*: 1 次治療中途で治療中断, †: 初診時に扣ける平均余命7 11).

の後, 死亡する数か月間は局所はコントロールされてい た。一方, 他の 1 例（症例 7 ）は肺炎のため, 2 次治療 は施行されなかった。

治療に伴ら副作用は 1 例を除く 9 例にみられた（表 3). 口内炎は 6 例に生じ最も多く, 他飞 沉血球減少 3 例, 肺炎, 低蛋白血症, 带状疮疹, 肺機能障害が各 1 例 に認められた。これらのほとんどは対症療法によって改 善しえたものの，肺炎をきたした症例 6 はそれが因で死 の転帰をとった。

血液検查から化学/放射線治療の副作用をみてみると, 尿素窒素 (BUN)，クレアチニンは治療による影響はあ まり認められず, 赤血球数 (RBC), ヘマトクリット $(\mathrm{Ht})$, 動脈中酸素分圧 $\left(\mathrm{PaO}_{2}\right)$ ，アルブミン $(\mathrm{Alb})$ は 治療によって低下したものの治療後には回復傾向を示し た。しかしながら，WBC，ChE は退院時な扮減少做向 にあり，治療の長期にわたる影響が認められた。な抦， 白血球数 (WBC) 和よび $\mathrm{PaO}_{2}$ を除き, $\mathrm{RBC}, \mathrm{Ht}$, Alb，コリンエステラーゼ (ChE) 打よび BUN は治療 前すでに対照患者に劣っていた（図2）.

治療後の経過としては, 生存が 2 例, 死亡 8 例であっ た（1992 年 6 月現在，表 4). 死因としては心・血管系 障害が 4 例, 肺炎 2 例, 老衰 2 例で, 病死のうちの 2 例 （症例 6，7）は死亡時, 担癌状態 であった。 1 次治療 開始から死亡むでの期間は, 最短 3 か月, 最長 5 年 4 か 月であり，死亡年㱓は 90 歳から94歳にわたり，死亡場所 としては自宅が 5 例と最も多かった。治療開始時におけ
る各患者の平均余命を上回って生存したのは，10例中 4 例であった。治療後の QOL は Good 2 例, Fair 6 例, Poor 2 例であり, 治療前より 3 例が 向上し 2 例が 悪化した。な扮, 生存例は現在, 96歳（症例 1 ）と91歳 （症例10）であるが， 2 人とも再発はなく，入院前と何 ら変わらぬ生活を送っている。

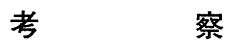

固形癌の発生率は加龄とともに増加し，20歳から80歳 までの各年齢層では直線的に上昇し，80歳ごろピークに 達するといわれている ${ }^{12)}$. 実際，80歳以上の人口比率は 約 $2.5 \%$ である ${ }^{13)}$ のに対し，頭頸部癌に打ける 80 歳以上 の占める割合は $7.8 \%$ から $17.8 \%$ と, 報告者 ${ }^{14 ~ 17) ~ に よ ~}$ って異なるものの高く, 当科では $8.5 \%$ 飞達していた。 富永は ${ }^{12}$ 加秢による発癌の増加の原因として, 損傷 DNA の蓄積, 発癌物質の蓄積, 免疫能の低下, などをあげて いる， 口腔領域ではこれらの促進因子に加兄，高齢者に は義歯が装着されていることが多く，これによる慢性刺 激, あるいはタバュ, アルコールをはじめとする発癌促 進物質に暴露される時間が長いことなどが，さらなる因 子としてあげることができるであろら。

口腔扁平上皮癌は $2: 1$ 以上の割合で男性に多発する ことが知られているが, 興味あることに, 本対象患者では 7 例ともすべてが女性であった。 この原因としては，高

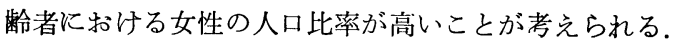




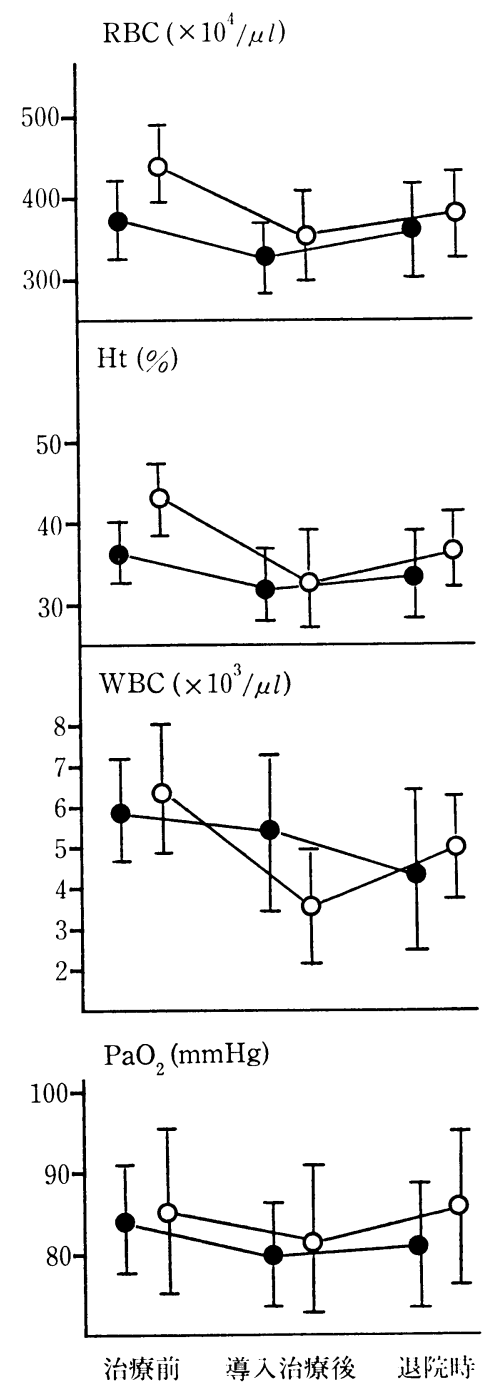

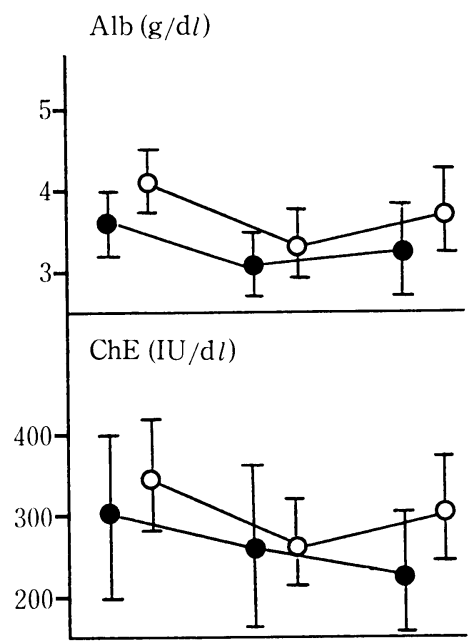

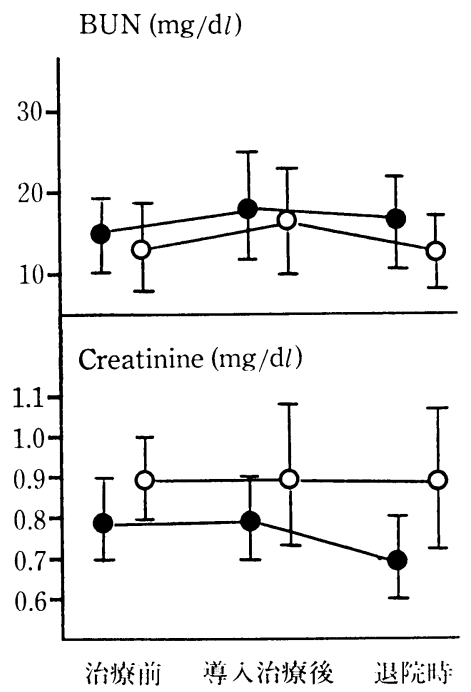

図 2 治療前, 導入療法終了時扣よび退院時に扣ける血液検査值の変動

-一○：対象患者（症例 2,6 を除く）

○一○：対照患者

しかし，そのことを考慮したとしても，女性の割合が高 すぎるように思われる。ささらに，部位についてみると， 舌, 口底は 1 例もなく, 歯肉が 6 例, 煩粘膜 1 例となっ ていた。これらの点がいかなる原因によるかは全くわか らないものの, 高㱓者における口腔粘膜癌の 1 つの特徵 として，女性拉よび歯肉に打ける頻発をあげることがで きよう。

高齢者の癌の特徴として, 高分化, 低成長, 限局性と いった点があげられる(18)。これらはいずれも悪性度の低 いことを意味し，治療上有利なこととしてとらえること ができる。しかし，実際には進行例が多いとの報告が多
く，たとえば，加藤ら ${ }^{19)}$ は70歳以上の頭頸部領域悪性腫 瘍患者の $91 \%$ が Stage III/Vであったとし, 大原ら ${ }^{20)}$ も 80歳以上の胃癌症例に扣いて Stage $\mathrm{V}$ が $70 \%$ も存在し たと述べている。本対象患者に拈いても Stage IV が多 く，7例の扁平上皮癌の組織像をみても 4 例までが中〜 低分化型であった。 したがって，高秢者では高分化型が 多いとは必ずしもいえないように思われる。初診時, Stage が進行しているものが多い原因は，異常を認識す ることが高齢者では遅れがちであること，さらには，異 常に気づいても障害がない限り，進んで治療を受けよう としないことが考えられ，増殖のスピードが早いためで 
はないように思われる。

リンパ節転移は対照患者に括けるとれと比較して高率 ではなかったが，高秢者の生理的特徵としての免疫能低 下にも目を向ける必要がある。加秢に伴ら細胞性免疫能 の低下，特に $\mathrm{T}$ 細胞機能の 低下は多くの研究者 $\left.{ }^{21} 23\right)$ が 示しているが，頭頸部悪性腫瘍に拈ける CD3 細胞およ び CD4 ${ }^{+} \mathrm{Leu}^{+}$細胞の減少, CD 57 細胞の増加ならび にリンパ球幼若化の低下などを指摘している論文もみら れる ${ }^{24)}$. 本検索結果では，そのことが明確に示され，加 えて, 担癌の影響を受けず治療によってもあまり变動し ないとされる NK 活性 ${ }^{25)}$ の低下が認められた。 T細胞の 反応性, NK 活性の低下は癌細胞の浸潤, 播種を容易に することより, 癌治療に際しては, 免疫能を賦活さす工 夫が必要と思われる，幸いなことに，LAK 活性は保た れていることより, リンパ球を適当な方法で刺激するこ とにより，非特異的障害能は良好に保つことができるで あろら。

高齢者に打ける癌治療の問題点の 1 つは，根本治療を ぞこまで追求するかという点である．対象10症例のうち 6 例に根本的治療が，そして 4 例に姑息的治療が行われ ていたが，その判断には患者の生理的年秢，合併症，気 力, 家族の理解度がまず優先して呯価され，加えて原発 巣の部位，大ささ，さらには転移リンパ節の予後の見达 を考慮し，治療が選択された。そして，手術による機能 障害を勘案し，可能な限りの腫瘍縮小を保存的治療に求 めた。今までは，術後の合併症を危惧するあまり，外科 治療は高齢者に拈いて避けられてきたが，十分な管理を 行えば相当の外科的侵襲にも耐えられることが次々に示 され，現在では高秢者に対する積極的な外科治療がさけ ばれている26,27)。ただ，口腔癌の進行，あるいは手術に よる組織欠損は患者の唯一の楽しみである食慨を奪うこ とにもなり，また，死因にもみられるがごとく，誤曣に よる肺炎が危惧される，その点に配慮がなされるなら ば，積極的な外科治療は放射線治療とともに，優れた局 所治療といえるであろう。

高粭患者では腫湟の性格を考虑して対処することも肝 要で, 患者の余命と病巣の進展速度を勘考することが大 切である，症例 2 に打ける耳下腺腫瘍は，初診時すでに 進展していたが，減量手術と 2 度にわたる化学/放射線 治療で残存腫瘍の増殖を 4 年か 8 月にわたってコントロ ールし，患者は天寿を全うしえた。このよらな経験から も，増殖スピードの遅い腫瘍の場合には，腫瘍と「共 存」しながら余命を送らしめることも，われわれは考え なくてはならないであろら。

高齢癌患者の治療を行っていく上で問題となるもの に，合併症と低下した予備力があげられる ${ }^{23)}$. 基礎疾患 としては諸家の報告と同様に，心・血管釈章害とともに 肺機能障害が多く，他に難聴，歩行障害がみられた。し かも， 1 人で多くの疾患を合せもつことが多く，症例 4

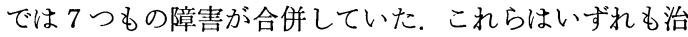
療を妨げる要因たりらるものの，病態としては平定した ものが汇とんどで，既存の合併症そのものが治療を大き く規制するものではなかった.むしろ，それよりも，や っかいなのは低下した予備力であり，骨䯣機能を中心と した臓器機能の低下が高秢患者の治療において最大の難 点のように思われる．予備力掞よび機能の低下は，一方 では，障害からの回復の遅延をも意味する，中でも骨髄 抑制, 低栄養状態からの回復は遅れ，化学/放射線治療 によってもたらされる顆粒球減少は，いずれの症例に拉 いてもその回復は遅く, $\mathrm{Alb}, \mathrm{ChE}$ は退院時に拈いても な抵下したままであった。

化学療法剤は大なり小なり骨髄抑制作用があり，他に も粘膜炎をはじめ多くの副作用を有する ${ }^{28,29)}$ ，高齢者の 生理的制約を考兵た時, 化学療法剤による全身治療より も，放射線治療あるいは手術による局所治療が有利のよ うに思われる。化学療法剤を用いたにしても，多剤を少 量用い，可及的に打の括のの副作用を抑光る努力が必要 であろら。われわれの用いた化学療法剂の用量は, 多量 すぎたように思われ，改変を要するものと思われる。た だ，口腔癌に適応される化学療法剤にあって，5 FUは 比較的副作用は少なく, 事実, $5 \mathrm{FU}$ と ${ }^{60} \mathrm{Co}$ との併用で は重篤な合併症は認められず，高齢者に拈ける療法とし て適しているように思われる，それと，副作用軽減のた めには，可及的に動脈内注入を試みることも大切であ ろら。さらに, “rescue”に対しても配慮することが肝 要で, 障害が重篤になるまでに, 顆粒球分化增殖因子 (granulocyte colony stimulating factor: G-CSF), 赤血 球増殖因子 (Erythropoetine) あるいはリンパ球抑制に 対する種々のサイトカインを投与することも得策であろ $5^{30,31)}$.

QOL は癌治療そのものだけに規約されるのではな く，患者の精神活動もQOL を大きく規制する，患者は 入院すると，家族から離れてしまった柾外感を感じ，病 気，治療に対する不安，治療による身体上のストレスな どが重なり，精神障害を若起する危険性が高くなり ${ }^{29)}$, 一方では，治療に非協力的となりやすい，その上，対象 患者のごとき高秢者は，往々にして「自分は十分すぎる 程，生きてきた。 もら無理をしてまで生きたくはない」 といら諦観を持ちやすい。これらの問題に対する最も良 い対処は，家族と加療者，患者が一体となることであ り，われわれは常に家族と連絡を取り，可能であれば付 さ添ってもららこととし，家族とともに病人の治療をす るように努力している。 その結果, 精神障害をきたした 例はなく，精神上の問題で治療の変更を余儀なくされた 例はなかった，対象とした10例のらち8例は，ほぼ満足 のいく生活を退院後も送り, 治療した意味があったよう に思われる．90歳前後といら超高齢者の癌治療は，高齢 であるがゆえの特別な配慮が必要であることが，この度 
の検討でもあきらかにしえたが，今後さらなる QOL の 向上を目指して, 治療法の改善を目指し, 工夫していか なくてはならないであろう。

\section{結語}

過去約10年間に当科において加療した 90 歳前後の悪性 腫場患者10例に対し，臨床的検討を行い以下の結果を得 た.

1. 対象とした 10 例は男 2 例，女 8 例からなり，組織 型別には扁平上皮癌 7 例（いずれも女性で， 1 例を除き 他は歯肉癌), 腺系癌 2 例, 悪性リンパ腫 1 例で, 9 例 の癌腫のうち 5 例が Stage IV であった。

2. 合併症は全例传認められ, 心・血管采障害, 換気 障害が 8 例と多く, 他に 難聴, 歩行障害 (各 3 例), 貧 血, 白内障 (各 2 例), 肝機能障害, 低蛋白血症 (各 1 例）が認められた。

3. 末梢血りンパ球中の $\mathrm{T}$ 細胞, 中でも Leu $8^{+}$細胞が 減少し, 逆に $\mathrm{CD} 16^{+} \mathrm{CD} 57^{+}$細胞が増加していた。ささら に, リンパ球幼若化, NK 活性の低下が認められたが, LAK 活性, 好中球の $\mathrm{O}_{2}^{-}$産生の低下はほとんど認めら れなかった。

4. 6 例飞根本的治療, 4 例飞姑息的治療 が 行われ， 前者のらちの 3 例, 後者の 1 例に CR が得られた. 局所 再発は 5 例に, 転移リンパ節の再発は 3 例中 2 例に生じ たが，2 次治療により，局所は全例，そして，転移リン パ節は 2 例のうち 1 例が制御された。

5. 副作用は 9 例飞生じ, 口内炎： 6 例, 沉血球減少: 3 例, 肺炎, 低蛋白血症, 带状疮疹, 肺機能障害 : 各 1 例であった。治療に伴い $\mathrm{RBC}, \mathrm{Ht}, \mathrm{WBC}, \mathrm{Alb}, \mathrm{ChE}$, $\mathrm{PaO}_{2}$ は低下乙, 中でも $\mathrm{WBC}, \mathrm{ChE}$ は退院時な和減少 傾向にあった。

6. 対象患者のうち 8 例は死亡し, 2 例はいまだ生存中 （治療より 2 年 7 か月, 4 年 3 か月）である. 治療開始時 に括ける各自の平均余命を上回ったのは 4 例であり，生 存中の QOL としては, Good 2 例, Fair 6 例, Poor 2 例であった。

以上の結果から, 高粭癌患者に対しては, 個々の患者 の精神，生理的特徽をふまえた総合的な見地から，治療 大綱を決定することが要求されることを述べた。ささら に, 副作用就よび低下した予備力に対処しつつ, 全身へ の影響の少ない放射線や手術を主体とした根本的治療が 有利であり，十全な精神的活動を保障しQOL の向上を 目指す必要があることを強調した。

本論文の要旨については, 第36回日本口腔外科学会総 会（1991年10月大阪）で報告した。

\section{引用 文 献}

1）厚生統計協会編：国民衛生の動向。厚生の指標 37: 388-401 1990 .

2）厚生統計協会編：国民衛生の動向，厚生の指標 38: 385-406 1991 .

3）大島 仁，米田和典，他：口腔瘦治療に打忷る 1 つの問題点一治療拒絶例括上び精神障害例に ついて一，日菜心身 3: 12-19 1988.

4) 岡部紘明：加齢と检查值，血液生化学検査。臨 検 33: 155-163 1989.

5) UICC, TNM: Classification of malignant tumors, 4 th Ed. International Union Against Cancer, Geneva, 1987.

6) Carbone, P.P., Spurr, C., et al.: Report of the committer on Hodgkins' disease staging classification. Cancer Res 31: 1860-1861 1971.

7）厚生統計協会編：国民衛生の動向．厚生の指標 30: 446-449 1983 .

8）厚生統計協会編：国民衛生の動向。厚生の指標 32: 406-407 1985 .

9）厚生統計協会編：国民衛生の動向，厚生の指標 33: 394-395 1986.

10）厚生統計協会編：国民衛生の動向，厚生の指標 35: 400-401 1988.

11）厚生統計協会編：国民衛生の動向。厚生の指標 36: 411-412 1989

12）富永祐民：加龄と癌。日本医師会雑誌 95：4324351986.

13）総務庁統計局: 平成 2 年:国势調査報告. 第 1 次 基本集計結果。 6-7 1990.

14）今井裕，鉿木克昌，他：当科飞招ける悪性 腫瘍の臨床統計的 観 察。口科誌 40: 631-639 1991.

15）平賀三嗣，上欈陸海，他：当科に扣ける過去 9 作間の顎口腔領域覀性腫瘍の臨床統計的観察。 日口外誌 36: 326-330 1990.

16）平山丈二, 早津良和, 他：当科飞打访る顎口腔 領域恶性腫演患者の臨床統計的 観察。口科誌 40: 415-422 1991.

17）金沢春幸，谷本良司，他：口腔噳の臨林統計 一教窒過去 10 年: の治燎成績一。 日外誌 36 : 2509-2517 1990.

18）太田邦夫：高齢者の㾿の特徽。癌と化学療法 13: 3105-3108 1986.

19）加藤洋子, 不户谷淳一, 他：当院に打ける项频

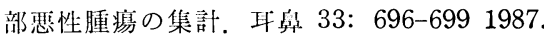

20）大原毅, 近藤芳夫, 他：超高齢者 (80歳以上)

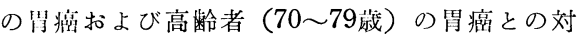
比。癌の臨 29: 37-40 1983.

21）松田 保：加齢と検查值，近液学的検査. 臨検 33: $176-1801989$.

22）尾崎登喜雄, 米田和典, 他 : 口腔粘膜癌のリン 節転移飞関寸る免疫学的㭘討。日癌治 25 : 
621-631 1990.

23）米田和典, 尾崎登喜雄, 他：高㱓者の口腔癌治 療に括ける副作用と合併症について。口科誌 40: 432-444 1991.

24）米田和典, 広田重水, 他: 頭頭部瘦70症例の免 疫学的検討一リンパ球サブセット，幼若化， NK 活性拉よび LAK 活性について一。 日口 外誌 38: 880-890 1992.

25) Ligthart, G.J., Schant, H.R., et al.: Natural killer cell function is not diminished in the healthy aged and is proportional to the number of NK cells in the peripheral blood. Immunology 68: 396-402 1989.

26) Shestak, K.C. and Jones, N.F.: Microsurgical free-tissue transfer in the elderly patient. Plast Reconstr Surg 88: 259-263 1991.

27) Coluccia, C., Ricci, E.B., et al.: Gastric cancer in the elderly: results of surgical treatment. INT SURG 72: 4-10 1987.

28) Lazarus, H.M., Vogler, W.R., et al.: Highdose cytosine arabinoside and daunorubicin as primary therapy in elderly patients with acute myelogenous leukemia. Cancer 63: 1055-1059 1989.

29) Vachon, M.L.S., Robinovitch, A., et al.: Cancer control and the older person. Cancer 68: 2534-2539 1991.

30) Valone, F.H., Gandara, D.R., et al.: Interleukin-2, cisplatin, and 5-fluorouracil for patients with non-small cell lung and head/ neck carcinomas. J Immunother 10: 207-213 1991.

31) Lindemann, A., Herrmann, F., et al.: Hematologic effects of recombinant granulocyte colony-stimulating factor in patients with malignancy. Blood 74: 2644-2651 1989. 